\title{
MONEY-DEMAND AND THE EFFICACY OF FISCAL POLICY
}

\author{
Saul H. HYMANS and John A. GARDNER \\ The University of Michigan, Ann Arbor, MI 48104, USA
}

Received September 1978

An M2 money-demand function including the market value of government debt is estimated. The resulting equation both tracks the recent movements in money-demand and has implications for the efficacy of fiscal policy as a tool of stabilization policy.

\section{Introduction}

It has been observed that the standard money-demand functions which had been in the literature through the early 1970 s were fooled by the rather substantial increases in the velocity of money which occurred in the mid-1970s. This phenomenon has been documented and studied by Goldfeld (1976) and by Enzler, Johnson and Paulus (1976), among others.

In a more theoretical vein, Solow and Blinder (1974) have clarified issues surrounding the efficacy of fiscal policy as a means of affecting (stabilizing) the path of real income. This has, however, raised an empirical question having to do, in part, with the money-demand function. Suppose a tax cut or other fiscal stimulus leads to an increase in the Federal deficit and the deficit is at least partially financed by the issuance of government bonds. If the increased stock of government bonds amounts to a net increase in private wealth and therefore raises consumer spending at any given level of income, the IS curve shifts upward to the right in the standard IS-LM diagram. If, in addition, the same debt increase, by itself, leads to an increase in the demand for money, the LM curve shifts upward to the left. This can lead to an ambiguity regarding the sign of the effect on real income of a standard fiscal stimulus policy. ${ }^{1}$ The essential issue here involves the algebraic difference $E_{D}-M_{D}$, where $E_{D}$ is the elasticity of expenditure with respect to government debt and $M_{D}$ is the elasticity of money-demand with respect to debt. A negative value for $E_{D}-$ $M_{D}$ may produce a perverse effect of fiscal policy on real income, whereas a posi-

\footnotetext{
1 A full and rigorous discussion of this issue may be found in Blinder and Solow (1974, pp. 45-57).
} 
tive value guarantees the "Keynesian" sign for the effect of a fiscal stimulus policy on real income. ${ }^{2}$

This paper reports an empirical result which speaks to both of the issues just raised. As part of a project undertaken to develop a new monetary sector for the Michigan Quarterly Econometric Model of the U.S. Economy (MQEM), we have estimated an M2 money-demand function which seems to be able to track recent movements in the velocity of money and also sheds light on the issue of whether a fiscal stimulus might have a perverse effect on real income. ${ }^{3}$

\section{The money-demand function}

Recent literature has tended to minimize the importance of the distinction between demand deposits and time deposits, and it has been noted that recent movements in money-demand are considerably less mysterious to $\mathbf{M} 2$ equations than to M1 equations. In our research we have concentrated on M2 as the basic monetary aggregate. Our money-demand function derives from a partial adjustment model in which desired (or equilibrium) money balances depend on income, interest rates, wealth and/or other non-money assets, and the rate of inflation. We estimate an equation of the form

$$
\begin{aligned}
\ln (M 2 / P)= & \alpha_{0}+\alpha_{1} \ln (\overline{G N P})_{-1}+\alpha_{3} \ln \left(G N P / G N P_{-2}\right) \\
& +\alpha_{4} \ln R T B \%+\alpha_{5} \ln R A A A \%+\alpha_{6}\left(\left(P-P_{-2}\right) / P_{-2}\right) \\
& +\alpha_{7} \ln \left(0.3 D M V P_{-1}+0.7 D M V P_{-2}\right)+\alpha_{8} \ln (M 2 / P)_{-1}+\epsilon,
\end{aligned}
$$

where

M2 = currency plus demand deposits plus time deposits (excluding large CDs), in billions of current dollars,

GNP = real GNP, in billions of 1972 dollars,

$\overline{G N P} \quad=$ "permanent" GNP, defined as a weighted average of current and past GNP's $\left(0.297 G N P+0.238 G N P_{-1}+0.190 G N P_{-2}+0.153 G N P_{-3}+\right.$ $\left.0.122 G N P_{-4}\right)$,

$R T B \% \quad=90$-day Treasury Bill rate, in percent,

$R A A A \%=$ Corporate Aaa interest rate, in percent,

$P \quad=$ the private non-farm business GNP deflator $(1972=1.0)$,

$D M V P \quad=$ the estimated market value of Federal government debt held by the private sector, end of period, in billions of 1972 dollars.

2 The last statement is correct if expenditures (e.g., investment) and money-demand have likesigned elasticities with respect to the rate or interest; see Blinder and Solow (1974, pp. 53-54).

${ }^{3}$ A report on the full monetary sector may be found in Gardner and Hymans (1978) and a recent version of MQEM is discussed in Hymans and Shapiro (1974). 
All the data are quarterly and are taken directly from standard data sources except for the real market value of Federal debt, $D M V P$. There are no published data on the market value of Federal debt outstanding. We have observed, however, that the average maturity of Federal debt has been close to four years during the postKorean period and this suggests the procedure of treating government debt as a four year bond paying the yield given by the $3-5$ year government bond rate. We have, therefore, approximated the market value of government debt by adding the capitalized value of Federal government interest payments and the present value of the current par value of the outstanding debt. ${ }^{4}$

The permanent GNP variable, $\overline{G N P}$, accounts for the normal transactions component of money-demand. We found that the presence of $\overline{G N P}$ in the equation foreclosed the ability to observe stable and statistically significant coefficients on variables such as financial asset wealth, stocks of consumer durables, etc. The variable $\ln \left(G N P / G N P_{-2}\right)$ accounts for short-run variation in money-demand due to speedups and slow-downs in economic activity.

The results of estimating the M2 money-demand function are shown in table 1 . We estimated the equation first through 1973 in order to determine lag-structures, experiment with different asset variables, etc., and then through 1975 to check for coefficient stability. This was particularly important in view of the possible shift in money-demand in the post-1973 period. It is clear from table 1 that our equation gives no evidence of instability in M2 money-demand between 1973 and 1975. A good part of this is due to the presence of $D M V P$ in the equation. The same equation without the market value of government debt does exhibit a good deal of instability in the 1974-75 period.

Further evidence of the tracking ability of eq. (3) in the table is provided by a number of static and dynamic simulations carried out over two year intervals within the sample period and for the post-sample period 1976-77. In the latter case, for example, the root mean squared error for 8 quarters of dynamic predictions of $\Delta(M 2 / P)$ is $\$ 3.9$ billion (1972 dollars) which is comparable to $\$ 4.0$ billion for the same experiment for 1974-75 and $\$ 3.6$ billion for 1970-71. 5

In short, our money-demand function - whether estimated through 1973 or through 1975 - finds nothing especially mysterious about the behavior of M2 in

${ }^{4}$ The formula used is

$$
D M V P \$=I \$ \sum_{j=0}^{15}(1+r)^{j}+D P V P \$(1+r)^{-15},
$$

where $D M V P \$$ is the current dollar market value of the Federal debt, $I \$$ is the current quarter interest on the Federal debt, DPVP\$ is the par value of Federal debt outstanding, and $r$ is the quarterly yield on 3-5 year government bonds.

5 Much more evidence regarding the M2 equation's tracking ability in the context of the full monetary sector may bc found in Gardncr and Hymans (1978). 
Table 1

Quarterly M2 money-demand functions. ${ }^{\text {a }}$

\begin{tabular}{lclllll}
\hline Eq. no. & $\begin{array}{l}\text { Sample } \\
\text { period }\end{array}$ & $\begin{array}{l}\text { Estimation } \\
\text { technique }\end{array}$ & Intercept & in $\overline{G N P}-1$ & in $\frac{G N P}{G N P_{-2}}$ & In RTR\% \\
\hline (1) & 1954 & OLS & -0.080 & 0.160 & 0.137 & -0.022 \\
& -73 & & $(-0.37)$ & $(4.60)$ & $(2.60)$ & $(-5.88)$ \\
(2) & 1954 & OLS & -0.081 & 0.152 & 0.121 & -0.021 \\
& -75 & & $(-0.40)$ & $(4.46)$ & $(2.31)$ & $(-6.12)$ \\
(3) & 1954 & I.V. b & -0.119 & 0.153 & 0.118 & -0.021 \\
& -75 & & $(-0.56)$ & $(4.29)$ & $(2.21)$ & $(-5.77)$ \\
\hline
\end{tabular}

a The dependent variable is $\ln (M 2 / P)$. Estimated $t$-ratios are shown in parentheses.

b The instrumental variable estimation procedure treated $M 2, R T B \%$, and $R A A A \%$ as jointly dependent. Predetermined variables were defined according to the overall structure of the MQEM.

recent years if the market value of government debt is permitted to help determine M2 money-demand.

\section{On the efficacy of fiscal policy}

The government debt variable enters our money-demand function with a negative sign. On the face of it, this might be interpreted as a denial of the view that government debt is private wealth. One might argue, for example, that a debt increase implies a corresponding increase in expected future tax liability so that private wealth should not be perceived as having been increased by virtue of an increase in government debt. But why the negative sign? The most obvious interpretation is simply that the government's bonded indebtness and M2 are alternative forms of liquidity, and the DMVP variable in the money-demand function is picking up the liquidity role of government debt. If so, there may still be room for government debt to have a more traditional wealth effect on money-demand. Regard permanent GNP, $\overline{G N P}$, as representing wealth via a relation of the form $\overline{G N P}=r(\bar{W}+$ $D M V P$ ), where $r$ is an appropriate interest rate and $\bar{W}$ is wealth other than DMVP. In equilibrium, and neglecting other variables in eq. (3), the money-demand function implies

$$
\begin{aligned}
\ln (M 2 / P) & =2.2 \ln \overrightarrow{G N P}-\ln D M V P \\
& =2.2 \ln r+2.2 \ln (\bar{W}+D M V P)-\ln D M V P .
\end{aligned}
$$

so that

$\partial \ln (M 2 / P) / \partial D M V P \cdot D M V P=2.2 r(D M V P / \overline{G N P})-1$. 


\begin{tabular}{|c|c|c|c|c|c|c|}
\hline $\ln R A A A \%$ & $\frac{P-P_{-2}}{P_{-2}}$ & $\begin{array}{l}\ln \left(0.3 D M V P_{-1}+\right. \\
\left.0.7 D M V P_{-2}\right)\end{array}$ & $\ln \left(\frac{M 2}{P}\right)_{-1}$ & $R^{2}$ & $S E E$ & $D W$ \\
\hline $\begin{array}{l}-0.039 \\
(-2.74)\end{array}$ & $\begin{array}{l}-0.374 \\
(-2.79)\end{array}$ & $\begin{array}{l}-0.083 \\
(-2.34)\end{array}$ & $\begin{array}{l}0.926 \\
(29.86)\end{array}$ & 0.999 & 0.0053 & 1.60 \\
\hline $\begin{array}{l}-0.039 \\
(-2.91)\end{array}$ & $\begin{array}{l}-0.454 \\
(-5.11)\end{array}$ & $\begin{array}{l}-0.082 \\
(-2.45)\end{array}$ & $\begin{array}{l}0.934 \\
(30.57)\end{array}$ & 0.999 & 0.0056 & 1.81 \\
\hline $\begin{array}{l}-0.036 \\
(-2.39)\end{array}$ & $\begin{array}{c}-0.457 \\
(-5.03)\end{array}$ & $\begin{array}{c}-0.074 \\
(-2.05)\end{array}$ & $\begin{array}{l}0.931 \\
(29.11)\end{array}$ & 0.999 & 0.0056 & 1.80 \\
\hline
\end{tabular}

At current values, $D M V P / \overline{G N P} \simeq 0.4$ so that the elasticity of money-demand with respect to government debt is of the order $0.85 r-1$ which is surely negative. Thus, the "liquidity role" of $D M V P$ dominates the wealth effect of $D M V P$ on moneydemand and - in the terminology introduced earlier - the elasticity $M_{D}$ is negative. As long as $E_{D}$, the elasticity of expenditure with respect to government debt, is non-negative, the expression $E_{D}-M_{D}$ is necessarily positive which guarantees the Keynesian sign for the effect of a tiscal stimulus on real income.

\section{References}

Blinder, Alan S. and Robert M. Solow, 1974, Analytical foundations of fiscal policy, in: Alan S. Blinder et al., The economics of public finance (Brookings Institution, Washington, DC) 3-115.

Enzler, Jared, Lewis Johnson and John Paulus, 1976, Some problems of money demand, Brookings Papers on Economic Activity 1, 261-280.

Gardner, John A. and Saul H. Hymans, 1978, An economic model of the U.S. monetary sector, RSQE Research Report (Department of Economics, The University of Michigan, Ann Arbor, MI).

Goldfeld, Stephen M., 1976, The case of the missing money, Brookings Papers on Economic Activity 3, 683-730.

Hymans, Saul H. and Harold T. Shapiro, 1974, The structure and properties of the Michigan Quarterly Econometric Model of the U.S. Economy, International Economic Review 15, Oct., 632-653. 